\title{
Optimization of preservation solutions to execute testing on cervical smear sample
}

\author{
Quang Thanh Le', Thanh Hai Pham², Quy Thi Cam Nguyen³, Quoc Phong Truong ${ }^{4}$, \\ Thi Thanh Tam Nguyen ${ }^{5}$, Thu Hang Pham ${ }^{6}$ \\ ${ }^{1}$ Director, ${ }^{2} \mathrm{Head}$, Quality Management Department, Tu Du Hospital, District 1, Ho Chi Minh, Vietnam, ${ }^{3}$ Researcher, \\ R\&D Department, ${ }^{5}$ Project leader, ${ }^{6}$ Chief Technology Officer, Bimedtech, Saigon Hi-Tech Park, District 9, Ho Chi Minh \\ city, Vietnam, ${ }^{4}$ Vice Dean, School of Biotechnology and Food Technology, Hanoi University of Science and Technology, \\ Hanoi, Vietnam
}

Background: The common methods to preserve cell for protein analyses are in cold condition or treated with freeze solution and packaging in dry ice for shipping. Solution which can preserve cervical cells at room temperature is preferable and cost consuming for laboratory testing. Aims and Objective: Research and optimized the storage and transport solution for cervical sample which can preserve cells at room temperature for laboratory testing. Materials and Methods: In this study, cervical specimens were collected in 3 different preservation solutions. Storage and transport of samples was at ambient or refrigerated temperature. The effect of preservation solution and temperature was check by cell visualization under microscope and protein measurement. Results: Presence of cells were detected in all three solutions. Among those, HEPES solution can preserve the highest number of cells and at room temperature.Conclusion: HEPES solution appeared suitable to preserve cervical cytology specimens at ambient temperature for further laboratory testing at protein and DNA level.

Key words: Cervical cancer; protein preservation solution; HEPES
Access this article online

\section{Website:}

http://nepjol.info/index.php/AJMS

DOI: 10.3126/ajms.v12i6.34299

E-ISSN: 2091-0576

P-ISSN: 2467-9100

Copyright (c) 2021 Asian Journal of Medical Sciences

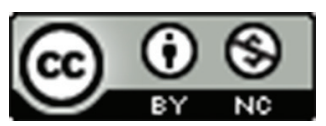

This work is licensed under a Creative Commons Attribution-NonCommercial 4.0 International License.

\section{INTRODUCTION}

Currently, the rate of cervical cancer has decreased significantly in countries around the world thanks to the implementation of cytological screening programs. However, the association between the formation of cervical cancer and the human tumor virus (HPV) has prompted scientists to find different methods of cervical cancer screening. ${ }^{1}$ In persistent infection of a high-risk type of HPV (HR-HPV), the interaction between oncoproteins HR-HPV E6 and E7 with tumor suppressor proteins $\mathrm{p} 53$ and $\mathrm{pRB}$ in cyclic regulation leads to a risk. development of cervical cancer. ${ }^{2}$ p16 INK4a (p16) is an inhibitor of cell proliferation during normal cell cycles. ${ }^{3} \mathrm{Ki} 67$ is a nuclear protein and a marker of cell proliferation. ${ }^{4}$ In a normal cell the expression of p16 and Ki67 is mutually exclusive, so the simultaneous detection of both proteins in one cell indicates a failure in cell cycle regulation. The main cause is the existence of the HPV virus. Therefore, we studied the expression of the protein p16 / Ki67 in the degree of cervical cell damage caused by HPV infection as a test to detect the risk of developing cervical cancer early in uterus. In order to perform protein-based assays, the cells after collecting patient samples should be properly stored to ensure that the extracted protein retains its natural structure and its bioactive. Currently, there are some cervical smear preservative solutions on the market for cytological tests, but these solutions are not suitable for our research. Therefore, we conducted this study with 
the aim to determine the cell preservative solution that helps maintain cell integrity and stability in cervical smear samples for protein isolation for downstream studies such as protein and DNA analyses.

\section{MATERIALS AND METHODS}

\section{Study design}

Retrospective case series. Cervical smear samples from the women who volunteered to participate in the study were collected at Tu Du Hospital from April to December 2020.

\section{Sample collection}

The smear was collected with a cervical brush following manufacturer's instructions and stored in vials with prepared preservative solutions. Sample were stored and transported under different conditions (room temperature and $4^{\circ} \mathrm{C}$ ). Different types of buffers used in this study was described in Table 1.

\section{Cell staining}

The obtained cell fluid is examined on a microscope with Trypan blue dye to check the cell morphology.

\section{Protein extraction procedure}

The patient samples were processed before extraction. Centrifuge the cells and the addition of cell-busting buffers to obtain proteins. Cell-busting buffers are NP-40 buffer $(150 \mathrm{mM} \mathrm{NaCl}, 1 \% \mathrm{NP}-40$ possible to substitute with $0.1 \%$ Triton X-100, $50 \mathrm{mM}$ Tris-HCl, $\mathrm{pH}$ 8.0, protease inhibitor) and RIPA buffer $(150 \mathrm{mM}$ $\mathrm{NaCl}, 1 \% \mathrm{NP}-40$ or $0.1 \%$ Triton X-100, $0.5 \%$ Sodium deoxycholate, $0.1 \%$ SDS, $50 \mathrm{mM}$ Tris-HCl, $\mathrm{pH} 8.0$, and protease inhibitor). Protein after extraction was checked

\begin{tabular}{lll}
\multicolumn{2}{l}{ Table 1: } & The types of buffer using in this study \\
\hline Number & Preservative solution & $\begin{array}{l}\text { Sample shipping and } \\
\text { storage condition }\end{array}$ \\
\hline 1 & PBS 1x buffer & $40 \mathrm{C}$ \\
2 & HEPES buffer & Room temperature \\
3 & MSwab buffer & Room temperature \\
\hline
\end{tabular}

for concentration and purity by Denovix DS-11 (Denovix Inc. USA).

\section{RESULTS}

Cervical sample collection: We collected cervical smear specimens from women who volunteered for the study at Tu Du Hospital. Each patient's patient sample was stored in 3 different types of solution, including: PBS 1x, HEPES, MSwab. Samples stored in PBS 1x solution were kept at $4^{\circ} \mathrm{C}$, samples stored in HEPES and MSwab solutions were kept at room temperature (Table 1).

Cell quality and stability: To determine the best cell preservative solution, we first evaluate the number and morphology of the cells in each different preservative solution. Cells that are unaffected under storage conditions are when intact cell membranes are not broken down. The cells after being treated and stained with Trypan blue were observed with a microscope. Staining results (Figure 1) show that: in all 3 solutions there is the presence of cells. However, the number of cells observed in PBS 1x and HEPES solution was more than that in MSwab solution. It is observed that the background in the sample of HEPES solution does not contain debris and is cleaner than the other two solutions. The observed cells have an intact morphology, the cell membrane is preserved, and the nucleus is clearly visible. It is possible that components in the HEPES buffer have resolved and eliminated red blood cells in the specimen, and at the same time protect the cervical cells integrity.

To evaluate the stability of HEPES solution in cell preservation, we stained and re-observed the cell morphology after different storage time, the results showed that this solution is capable of maintain cell stability.

To evaluate the cell stability in three solutions, we stained and re-observed the cell morphology at different storage time $24 \mathrm{~h}$ hours, 48 hours, 7 days and 14 days. After 24 and

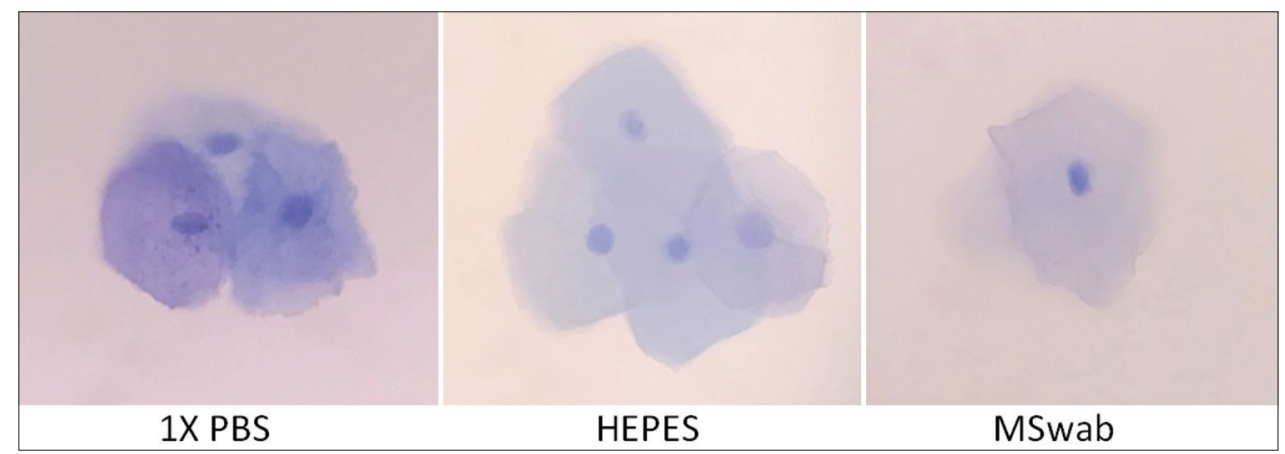

Figure 1: Results of staining and cytology in preservative solutions 


\begin{tabular}{|c|c|c|c|c|}
\hline Type of buffer & Sample & Number of cells & Volume $(\mu \mathrm{l})$ & Protein concentration $(\mu \mathrm{g})$ \\
\hline \multirow[t]{6}{*}{ PBS 1x } & 2DA001 & +++ & 300 & 25.2 \\
\hline & 2DA002 & ++ & 200 & 88 \\
\hline & 2DA003 & + & 100 & 29.7 \\
\hline & 2DA004 & ++++ & 400 & 194.4 \\
\hline & 2DA005 & ++ & 300 & 63.9 \\
\hline & Mean & 2.4 & & 80.24 \\
\hline \multirow[t]{6}{*}{ HEPES } & 2DA006 & ++ & 200 & 46 \\
\hline & 2DA007 & ++ & 200 & 126.6 \\
\hline & 2DA008 & +++ & 300 & 381.1 \\
\hline & 2DA009 & ++ & 200 & 161.4 \\
\hline & 2DA010 & + & 300 & 23.1 \\
\hline & Mean & 2.0 & & 147.64 \\
\hline \multirow[t]{6}{*}{ MSwab } & 2DA011 & + & 100 & 38.9 \\
\hline & 2DA012 & + & 100 & 18 \\
\hline & 2DA013 & + & 100 & 51.2 \\
\hline & 2DA014 & ++ & 200 & 106.4 \\
\hline & 2DA015 & +++ & 200 & 69.9 \\
\hline & Mean & 1.6 & & 56.88 \\
\hline
\end{tabular}

48 hours, the cell number and morphology did not show significant change in all three solutions. But after 7 days, no cell was observed in MSwab solution, there were some cells but with many cell debris in PBS 1x solution, while HEPES maintain cell morphology and no significant change in number of cells. Besides that, for storing cell in PBS 1x, sample should be kept at $4^{\circ} \mathrm{C}$ while in HEPES sample can be stored at room temperature, which is much more convenient and low cost for transporting and storing samples.

\section{Total protein quantity}

Unlike tests performed on DNA objects, tests performed on protein molecules require extremely strict preservation of patient samples, since proteins are easily degraded and bioactive when exposed with chemicals in the preservative or extraction solutions. Therefore, we investigate some solutions to find a preservative solution that can stabilize the cell to ensure the cell is intact to retain the structure and activity of the protein after extraction. Samples of specimens after being collected and stored in different solutions were extracted for protein. The results of protein extraction were described in Table 2 , the number of cells in the storage solutions is different, the cause may be due to the sampling process, the number of cells put into the storage vials is not heterogeneous. After protein extraction, the protein content obtained was highest when stored in HEPES solution and lowest when cells were stored in MSwab solution. When cells were stored in PBS $1 \mathrm{x}$ buffer the highest number of cells were counted, but when protein was extracted, the protein content obtained was lower than when storing cells with HEPES buffer. Thus, we found that HEPES solution is a good biological buffer that maintains cell stability during storage.

\section{CONCLUSION}

In this study, we have investigated and optimized the storage solution of cervical smear specimens collected with a Cervical brush. With the selected preservative solution, cells in the post-obtained cervical smear specimens were maintained stable. One the other hand, this selected solution only require maintaining at room temperature, which is very convenient for sample transporting and storage with low cost. Hence, we can use this solution for further testing of cervical smear samples at protein and DNA levels.

\section{ACKNOWLEDGEMENT}

The authors would like to thank Tu Du hospital for providing the samples and thank Bimedtech for supporting this study.

\section{REFERENCES}

1. Walboomers JM, Jacobs MV, Manos MM, Bosch FX, Kummer JA, Shah $\mathrm{KV}$, et al. Human papillomavirus is a necessary cause of invasive cervical cancer worldwide. The Journal of Pathology. 1999; 189(1):12-19.

https://doi.org/10.1002/(SICI)1096-9896(199909)189:1<12::AID -PATH431>3.0.CO;2-F

2. Ghittoni R, Accardi R, Hasan U, Gheit T, Sylla B and Tommasino M. The biological properties of E6 and E7 oncoproteins from human papillomaviruses. Virus Genes. 2010; 40(1): 1-13. https://doi.org/10.1007/s11262-009-0412-8

3. M von Knebel Doeberitz. New markers for cervical dysplasia to visualise the genomic chaos created by aberrant oncogenic papillomavirus infections. European Journal of Cancer. 2002; 38(17): 2229-2242.

https://doi.org/10.1016/S0959-8049(02)00462-8 
4. Menon SS, Guruvayoorappan C, Sakthivel K M and Rasmi RR. KiInternational Journal of Clinical Chemistry. 2019; 491: 39-45. 67 protein as a tumour proliferation marker. Clinica Chimica Acta;

\begin{abstract}
Authors contribution: design and manuscript revision.

\section{Work Attributed to:}

Bimedtech, Saigon Hi-Tech Park, District 9, Ho Chi Minh, Vietnam.

Orcid ID:

Dr. Quang Thanh Le - (1) https://orcid.org/0000-0001-6589-6088

Dr. Thanh Hai Pham - (1) https://orcid.org/0000-0002-0263-1055

Quy Thi Cam Nguyen - (D) https://orcid.org/0000-0002-3722-0096

Dr. Quoc Phong Truong - (D) https://orcid.org/0000-0003-3709-6416

Dr.Thi Thanh Tam Nguyen - (1) https://orcid.org/0000-0001-8724-5155

Dr. Thu Hang Pham - https://orcid.org/0000-0002-6218-420X
\end{abstract}

QTL, THP- Patient counseling and providing samples; QTCN, QPT- Concept the study, data collection and analysis; TTTN-Manuscript preparation; THP- Study

Conflict of Interest: None, Source of Funding: Project: "Application of protein array technology to produce and validate the kit for fast detection of biomarkers p16 and Ki67 in cervical screening", code 004.19.CNC.QG/HDKHCN. 